\title{
当院における超高齢者大腿骨近位部骨折両側発生数の年次変化
}

\author{
坂 元 裕一郎* 松 永 俊 二* 八 尋 雄 平* 堀 川 良 治* \\ 東 福 勝 宏* 古賀 公 明* 今給黎 尚 典* 小宮 節 郎**
}

\section{Yearly Change of Bilateral Hip Fracture in the Oldest-Old Female Patients}

\author{
Yuichiro Sakamoto*, Shunji Matsunaga*, Yuhei Yahiro*, Yoshiharu Horikawa*, \\ Katsuhiro Tofuku*, Hiroaki Koga*, Takanori Imakiire*, and Setsuro Komiya**
}

\begin{abstract}
強力な骨折抑制効果のある骨粗鬆症薬の開発にもかかわらず日本の大腿骨近位部骨折の発生頻度は増加 している. 本研究では当院に扔ける超高齢女性の大腿骨近位部骨折手術例の頻度を両側発生例中心に調査 した. 2004 年〜2010 年における当院での大腿骨近位部骨折手術例を電子カルテデータベースから年度別 に抜き出し両側手術例数と骨粗鬆症治療薬使用との関係を調べた。全女性大腿骨近位部骨折例に対する 85 歳以上女性症例の割合は経年的有意な変化はなかった。一方 85 歳以上女性の両側骨折手術例の割合は 2004 年が $17.5 \%$ であったが 2010 年は $9.2 \%$ と減少していた。この間に 85 歳以上女性患者に対するビス フォスファネ一トやSERM の使用率はいずれも低率であった。両側大腿骨近位部骨折の頻度の減少には 骨粗鬆症治療薬以外の因子が関与していると思われた。
\end{abstract}

The number of hip fracture continues to increase, despite the development of drugs for osteoporosis. We studied the yearly change of hip fractures in oldest-old female patients treated at our hospital with particular reference to bilateral fractures. We reviewed hip fracture in females between 2004 and 2010 by an electronic health record system, focusing on the incidence of bilateral fractures and the relationship between incidence and taking of osteoporosis drug. The ratio of the oldest-old patients with total hip fracture did not change significantly. However, the ratio of bilateral hip fractures in oldest-old females decreased from $17.5 \%$ in 2004 to $9.2 \%$ in 2010. In this period, the usage rate of bisphosphonate and Selective Estrogen Receptor Modulator (SERM) in oldest-old females was low. Decrease in bilateral hip fractures in oldest-old females may involve factors other than osteoporosis drugs.

Key words：osteoporosis（骨粗鬆症)，hip fracture（大腿骨近位部骨折），oldest-old（超高齢者）

\section{はじめに}

骨粗鬁症患者の増加により大腿骨近位部骨折も増加 している，大腿骨近位部骨折は患者の生命予後に影響 する重大な疾患であると認識されているが，残念なが ら一側の大腿骨近位部骨折に対して治療を行ったにも かかわらず再度反対側を骨折して再入院する患者も少 なくない. 本研究では当院に扔ける 85 歳以上超高齢 者の大腿骨近位部骨折両側発生例の年次変化を調査 し，またその変化に影響する因子を検討したので報告 する。
方法

2004 年 2010 年の過去 7 年間の女性大腿骨近位部 骨折当院入院患者を電子カルテで調査し年次变化を検 討した。また，骨折治療後の生活環境, 85 歳以上の同 骨折患者の骨粗髧症治療薬内服状況を調查した.

結 果

当院に打ける女性大腿骨近位部骨折入院数は経年的 に増加しており，2010 年は 2004 年の 1.5 倍であっ た。このうち高齢者の占める割合は 75 歳以上で約

* 今給黎総合病院整形外科 Department of Orthopedic Surgery, Imakiire General Hospital, Kagoshima, Japan

** 鹿児島大学大学院運動機能修復学講座整形外科学 Department of Orthopedic Surgery, Kagoshima Graduate School of Medical and Dental Sciences, Kagoshima University, Kagoshima, Japan 
80\% であり， 85 歳以上の超高齢者も $40 \%$ あった。両 側発生例数の年次変化をみると, 75 歳以上では大き な変化は認めなかったが，85歳以上の超高齢者につ いては 2006 年以降それ以前の 16\% から 10\% 以下へ と著しく減少していた (図 1).

85 歳以上の両側発生の減少への骨粗鬆症治療の影 響を検討するため骨粗鬆症治療薬の服用状況を調査し たところ，60\% 以上が未治療であり，ビスホスホネー 卜製剤服用は $5 \%$ 程度でしかなかった（図 2).また，

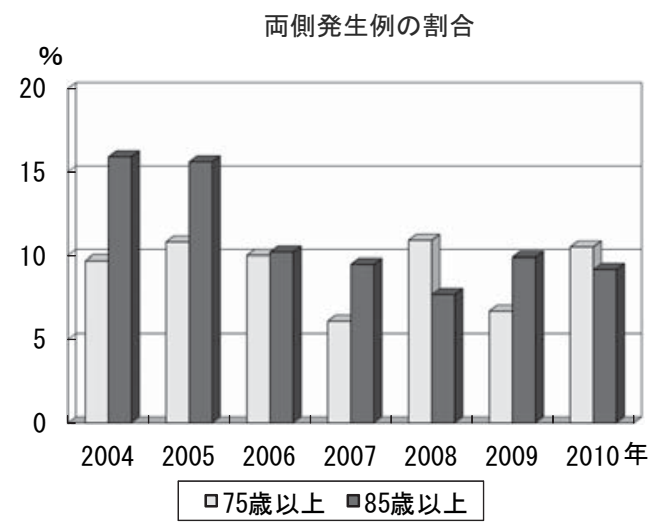

図 1 年齢別両側発生の年次変化 大腿骨近位部骨折の両側発生例は 75 歳以 上では年次変化を認めないが，85 歳以上に おいては 2006 年以降減少を認めた。

85 歳以上女性の大腿骨近位部骨折後における 骨粗鬆症薬使用状況

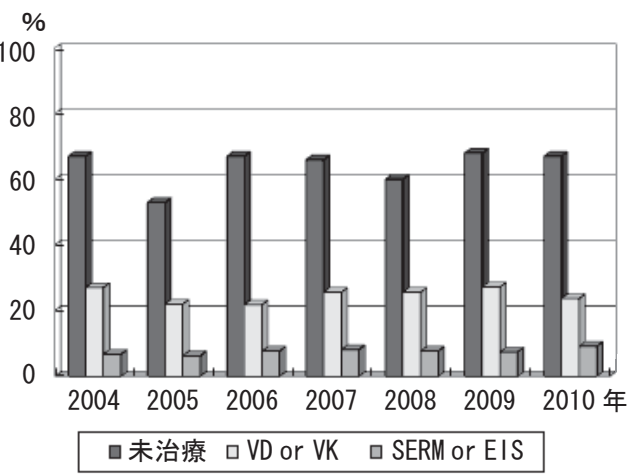

図 2 超高齢者での骨粗鬆症治療状況 大腿骨近位部骨折の加療後においての骨粗 鬆症薬の使用状況の調査で, 未治療例が 60\% と大多数を占めていた. ビスホスホ ネートの内服例は 10\% 以下であった.
超高齢女性の大腿骨近位部骨折後の生活の場

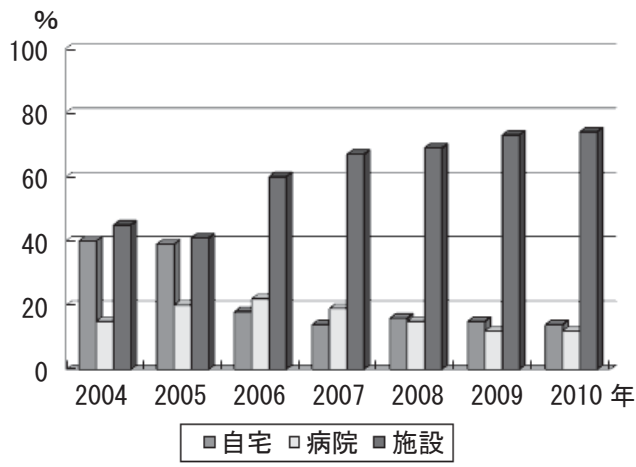

図 3 骨折治療終了後の生活環境 2006 年以降 骨折治療終了後施設入所者が増 加し, 自宅生活者が減少していた。この傾向は 地域連携パスに導入によるものと考えられた。

大腿骨近位部骨折治療終了後の生活がどこでなされて いたかを調べると，2006 年以後は施設への入所が増 加しており, 自宅生活者は減少していた（図3).

\section{考察}

骨粗鬆症患者の増加により大腿骨近位部骨折も増加 している。日本における骨粗鬆症の有病率は年齢とと もに増加し 75 歳以上では $50 \%$ を超え，さらに今後人 口の高齢化とともにこの骨粗鬆症の有病率はさらに増 加すると考えられている ${ }^{1)}$. 骨粗鬆症の増加と関連し て大腿骨近位部骨折も増加すると考えられており, 2030 年には 2000 年の約 2 倍になると予想されてい $る^{2)}$. 有効な骨折抑制効果のある骨粗鬆症治療薬が開 発されてから，海外では大腿骨近位部骨折の頻度は減 少したとする報告がある ${ }^{3)}$.しかし，残念ながら日本 ではいまだに大腿骨近位部骨折の発生は増加してお り, 今回の調査でも同様の結果が得られた.

有効な骨折抑制効果のあるとされている骨粗鬆症治 療薬が開発され，当院でも適宜採用しているが，実際 には超高齢者大腿骨近位部骨折患者には使用されてい ないことが確認された。その理由は一様ではないが, ビスホスホネート製剤の内服方法の煩雑さ，座位保持 が必要なビスホスホネート製剤の服用が大腿骨骨折急 性期では実際は困難なこと，骨吸収抑制剂が骨折治癒 を障害するのではないかという不安などが考えられ る。また本症における地域連携パスが採用された結 
果，DPCの関係から経営上の理由で影響から転院先 での加療がリハビリ中心となり基礎疾患である骨粗鬆 症治療がおざなりになっていることなどが考えられ た。

本研究により，骨折予防に有効な骨粗鬆症治療は実 際の行われていないことが確認された。骨粗鬆症治療 をさらに厳重に行えば大腿骨近位部骨折の再発頻度は さらに減少すると考えられる。

\section{結玨 語}

今回の調査では 85 歳以上超高齢者の大腿骨近位部 骨折の両側発生率は 2006 年以後減少していたが，こ れは骨粗鬆症治療薬の効果ではなく，患者介護体制の
変化によるものが考えられた。骨粗鬆症治療をさらに 厳重に行えば大腿骨近位部骨折の再発頻度はさらに減 少すると考えられた。

\section{文献}

1）福永仁夫：骨粗鬆症罹患率の推定. Osteoporosis Jpn., 10(1) : 11-13, 2002.

2）萩野 浩：大腿骨頸部骨折の発生状況. Osteoporosis Jpn., 10(1) : 18-20, 2002.

3) Jaglal, S. B., et al. : Population trends in BMD testing, treatment, and hip and wrist fracture rates : are the hip fracture projections wrong?. J. Bone Miner. Res., 20 (6) : 898-905, 2005. 